\title{
200 years of isotope and chemical records in a firn core from Hercules Névé, northern Victoria Land, Antarctica
}

\author{
B. Stenni, ${ }^{1}$ R. Caprioli, ${ }^{2}$ L. Cimino, ${ }^{2}$ C. Cremisini, ${ }^{2}$ O. Flora, ${ }^{1}$ R. Gragnani, ${ }^{2}$ \\ A. Longinelli, ${ }^{1}$ V. Maggi, ${ }^{3}$ S. Toraini ${ }^{2}$ \\ ${ }^{1}$ Dipartimento di Scienze Geologiche, Ambientali e Marine, Università di Trieste, Via E. Weiss 2, I-34127 Trieste, Italy \\ ${ }^{2}$ Ente per le Nuove Tecnologie, l'Energia e l'Ambiente, AMB, Centro Richerche Energia Casaccia,Via Anguillarese 301, I-00100 Rome, Italy \\ ${ }^{3}$ Dipartimento di Scienze dell'Ambiente e del Territorio, Università di Milano, Via Emanueli 15, I-20126 Milan, Italy
}

\begin{abstract}
A $42.2 \mathrm{~m}$ firn core was collected at the Hercules Névé plateau $(100 \mathrm{~km}$ inland and $2960 \mathrm{~m}$ a.s.l.), northern Victoria Land, during the 1994-95 Italian Antarctic Expedition. Chemical $\left(\mathrm{Cl}^{-}, \mathrm{NO}_{3}{ }^{-}, \mathrm{SO}_{4}{ }^{2-}\right.$ and $\left.\mathrm{H}_{2} \mathrm{O}_{2}\right)$ and isotope $\left(\delta^{18} \mathrm{O}\right)$ analyses were performed to evaluate the snow-accumulation rate at this site. Tritium measurements were performed in the upper part of the core to narrow down the dating of the core.

High nss $\mathrm{SO}_{4}{ }^{2-}$ concentrations seem to be related to some explosive volcanic eruptions, such as Tambora (AD 1815) and the preceding event called "Unknown" (AD 1809), Coseguina (AD 1835), Makjan (AD 1861), Krakatoa (AD 1883) and Tarawera (AD 1886).

A comparison between the seasonal variations observed in the isotope and chemical profiles was carried out in order to reduce the dating uncertainty, using the tritium and the volcanic markers as time constraints. A deposition period of 222 years was determined.

The 3 year smoothed $\delta^{18} \mathrm{O}$ profile shows more negative values from the bottom of the core (dated AD 1770) throughout the 19th century, suggesting "cooler" conditions, in agreement with other East Antarctic ice-core records. Subsequently, a general increase in $\delta^{18} \mathrm{O}$ values is observed.

The calculated average snow-accumulation rates between the above-mentioned time markers are $111-129 \mathrm{~kg} \mathrm{~m}^{-2} \mathrm{a}^{-1}$.
\end{abstract}

\section{INTRODUGTION}

Major explosive volcanic eruptions emit large amounts of gas (mainly $\mathrm{SO}_{2}$ ) and dust into the stratosphere; they may be an important cause of weather and temperature variations (Hammer and others, 1980; Robock and Mass, 1982; LaMarche and Hirschboeck, 1984; Robock and Free, 1995; Briffa and others, 1998). The main effect of the emission of dust into the stratosphere is its heating through the absorption of solar radiation (Baldwin and others, 1976; Hansen and others, 1978), whereas sulphuric acid particles, coming from oxidation of $\mathrm{SO}_{2}$, scatter the sunlight and produce a cooling of the lower troposphere. Moreover, the sulphate aerosol absorbs longwave radiation, warming the stratosphere. In order to evaluate the volcanic load of the atmosphere in recent years, direct measurements were taken during the Pinatubo, El Chichon and Mount St. Helen eruptions (Robock, 1981; Kerr, 1983; Hansen and others, 1992), but for the old eruptions indirect evaluations can be made (Robock and Free, 1995). Due to the global distribution of volcanic sulphur dioxide, subsequently oxidised to sulphate, which can produce a strong acid signal in ice sheets, a promising ice-core--volcanic index has been suggested (Legrand and Delmas, 1987; Robock and Free, 1995) for evaluating the global impact of eruptions. The study of these volcanic spikes is important for evaluating the relationship between climate and volcanism. Moreover, volcanic markers are very useful for improving the dating accuracy of ice cores by multiple-parameter analyses.

This paper reports new chemical and isotope data on a firn core $(0.5-42.2 \mathrm{~m}$ deep) collected at the Hercules Névé plateau (100 km inland and $2960 \mathrm{~m}$ a.s.l.), northern Victoria Land (Fig. 1), during the 1994-95 Italian Antarctic Expedition. The core extends back to AD 1770 and provides a record

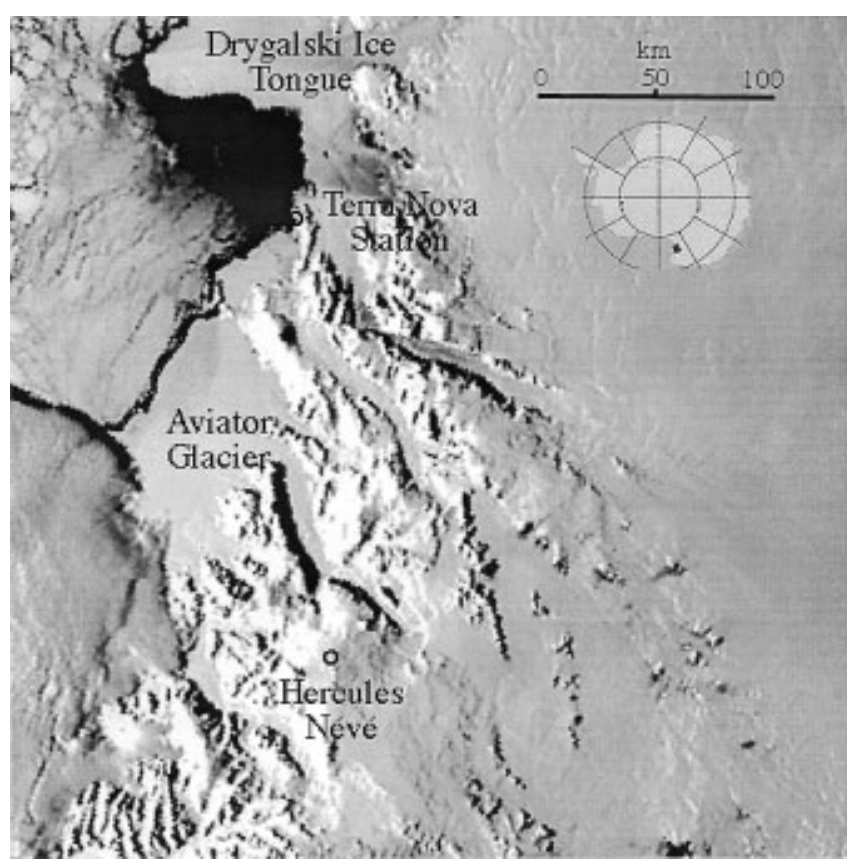

Fig. 1. Location of ice-core site at Hercules Névé, northern Victoria Land. 
of $\delta^{18} \mathrm{O}$ data encompassing part of the so-called Little Ice Age (LIA). This "colder" period was reconstructed from Northern Hemisphere temperatures (Groveman and Landsberg, 1979) and proxy records (Grove, 1988). Lamb (1977a) placed this episode between AD 1550 and 1850. From a series of proxy data of different origin, Jones and Bradley (1992) argued that the LIA was characterised not by a single long-lasting cold period but by a number of colder intervals. Moreover, the coldest periods do not coincide between different geographical regions, and the temporal distribution varies from one area to another. All these considerations on the temporal and spatial variability of this cold event suggest some caution in using the term LIA. The geographical and temporal distribution of this event in Antarctica is still unclear, and new proxy data are needed for a better understanding of its global extent.

A comparison between $\delta^{18} \mathrm{O}$ average values and surface temperatures in Antarctica is possible only for the last decades of the 20th century; the ice-core records are therefore a valuable tool providing detailed information for periods not covered by instrumental weather observations. Furthermore, the study of the past natural variability of the environmental system has attracted fresh attention after the recent observations of anthropogenically induced climate change (Houghton and others, 1996).

\section{SAMPLING AND ANALYSES}

The core sections, after surface cleaning in a cold room, were subsampled every $3-4 \mathrm{~cm}$. Samples were kept frozen and stored in pre-cleaned (with $18 \mathrm{M} \Omega$ ultra-pure water) polyethylene containers. The samples were then melted in a clean room prior to chemical analysis. Chemical $\left(\mathrm{Cl}^{-}\right.$, $\mathrm{NO}_{3}{ }^{-}, \mathrm{SO}_{4}{ }^{2-}$ and $\left.\mathrm{H}_{2} \mathrm{O}_{2}\right)$ and isotope $\left(\delta^{18} \mathrm{O}\right)$ analyses were performed in order to evaluate the snow-accumulation rate at this site. Tritium measurements were performed in the upper part of the core, between about 4.5 and $11 \mathrm{~m}$, in order to identify the 1965-66 tritium peak due to the 1961-62 thermonuclear atmospheric bomb test (Jouzel and others, 1979). The analytical procedures for the chemical, isotope and tritium measurements are described elsewhere (Gragnani and others, 1998; Maggi and others, 1998).

\section{RESULTS AND DISGUSSION}

During the early 1950s and 1960s thermonuclear atmospheric bomb tests emitted large amounts of artificial radionuclides into the Earth's atmosphere (particularly during 1952-54 and 1961-62). The fallout of radionuclides following these periods produced marked concentration levels of artificial tritium that can be used in the firn as dating markers. Due to the delay between tritium emission and fallout, the 196162 tests produced the most important tritium peak at the South Pole in 1966 (Jouzel and others, 1979).

In the Hercules Névé core the tritium concentration ranges between 0 (1027 $\mathrm{cm}$ depth) and 33.6 (845 cm depth) TU (tritium unit, 1 TU corresponding to $T / H=10^{-18}$ ), with higher concentrations found at $700-845 \mathrm{~cm}$ (Fig. 2). Due to the low sampling frequency for tritium measurements, not allowing any observation of seasonal variations, a secondorder polynomial curve was calculated and its apex was chosen as 1966 at about $7.5 \mathrm{~m}$ depth. This corresponds per-

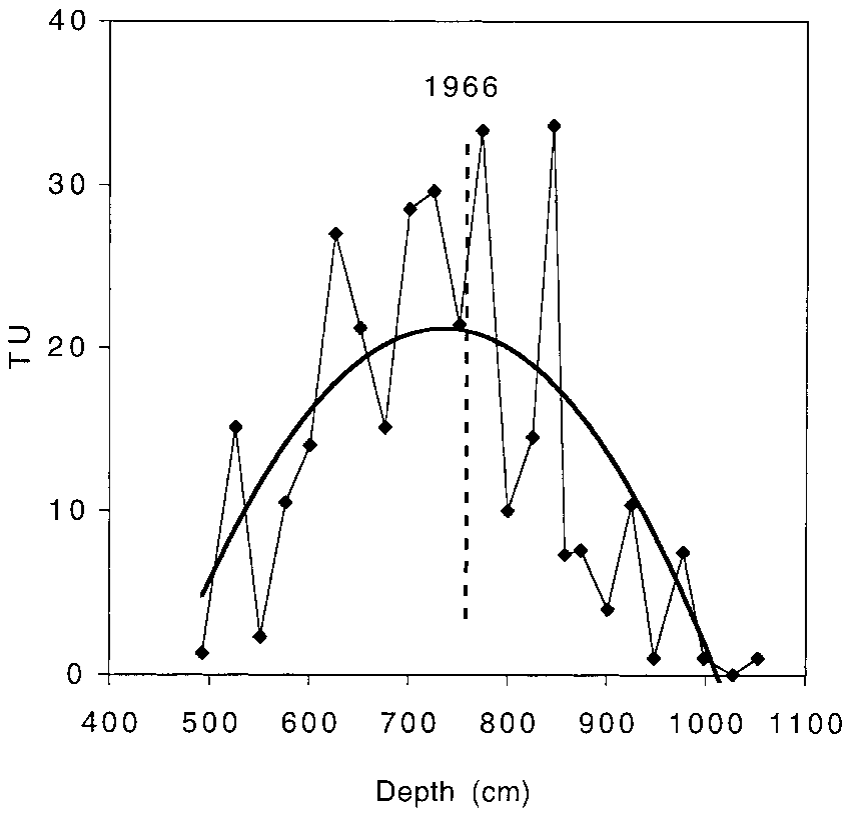

Fig. 2. Tritium content os depth; the curve in bold represents a second-order polynomial regression fit.

fectly to the year suggested by the seasonal variations of the chemical and isotope parameters.

Figure 3 shows the chemical and isotope profiles of the first $6 \mathrm{~m}$ of the core.

The stable-isotope composition of atmospheric precipitation preserved in polar regions mainly reflects condensation temperature (Dansgaard, 1964) but also reflects changes in moisture sources (Charles and others, 1994), variations of sea-ice extent (Bromwich and Weaver, 1983) and seasonal variations in the timing of precipitation events (Steig and others, 1994). The $\delta^{18} \mathrm{O}$ values in the upper part of the core range between $-42.9 \%$ and $-28.0 \%$ (Vienna standard mean ocean water), the observed variations being related to seasonal variations of this parameter. The calculated overall mean $\delta^{18} \mathrm{O}$
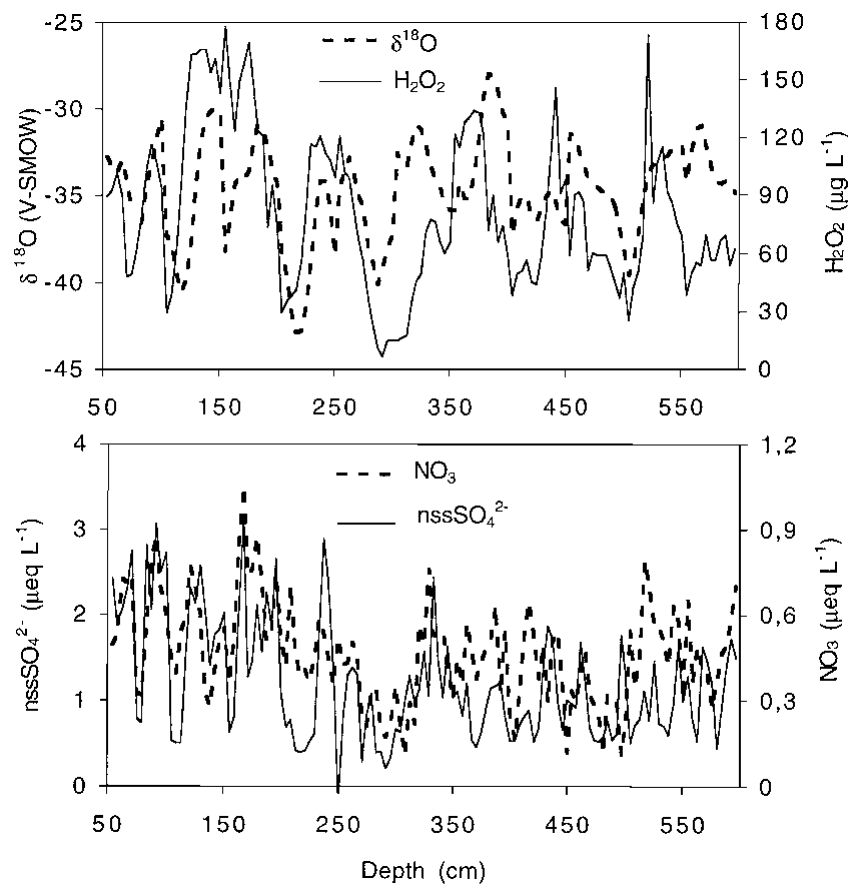

Fig. 3. $\delta^{18} \mathrm{O}, \mathrm{H}_{2} \mathrm{O}_{2}$, nss $\mathrm{SO}_{4}{ }^{2-}$ and $\mathrm{NO}_{3}{ }^{-}$profiles in the upper part of Hercules Névé core. 
value is $-35.38 \%$. The amplitude of the $\delta^{18} \mathrm{O}$ seasonal variation decreases with depth (Fig. 3) because smoothing processes act more effectively in the firn layers when accumulation rates are quite low (Johnsen, 1977).

The atmospheric concentration of hydrogen peroxide is modulated by photochemical processes which reach their maximum intensity during summer. At Hercules Névé the $\mathrm{H}_{2} \mathrm{O}_{2}$ concentration shows a median value of $38 \mu \mathrm{g} \mathrm{L} \mathrm{L}^{-1}$, with higher concentrations in the upper part of the core, while below $20 \mathrm{~m}, \mathrm{H}_{2} \mathrm{O}_{2}$ values decrease and the profile is smoothed out. At the South Pole, where the accumulation rate is about $7 \mathrm{~g} \mathrm{~cm}^{-2} \mathrm{a}^{-1}$ (Langway and others, 1995), a $6 \mathrm{~m}$ snow pit was studied (Whitlow and others, 1992), but $\mathrm{H}_{2} \mathrm{O}_{2}$ was not used as a dating parameter due to the poor relationship with $\delta^{18} \mathrm{O}$ peaks and a smoothing effect with increasing depth. At sites with higher accumulation rates, the "dramatic" $\mathrm{H}_{2} \mathrm{O}_{2}$ smoothing was not observed (Morgan and others, 1997), and this compound was used as a time-scale parameter. This difference may be related to post-deposition processes that complicate the $\mathrm{H}_{2} \mathrm{O}_{2}$ profile, particularly in the case of low accumulation rates. The $\mathrm{H}_{2} \mathrm{O}_{2}$ was therefore used as a timescale parameter only in the upper part of the core $(0.5-10 \mathrm{~m})$.

The most important sources of $\mathrm{Cl}^{-}$in Antarctica are sea water and volcanic emissions, although near the coast the latter are negligible (Legrand and Delmas, 1988). At Hercules Névé the medianvalue of the $\mathrm{Cl}^{-}$concentration is $2.62 \mu \mathrm{eq} \mathrm{L}^{-1}$ (mean $=5.36 \mu \mathrm{eq} \mathrm{L}^{-1}$ ). This is much lower than the value found in the coastal area of Terra Nova Bay (Piccardi and others, 1994; Gragnani and others, 1998) but higher than the value found at other Antarctic sites at lower elevations than Hercules Névé. At Dyer Plateau (about 2000 m a.s.l.) the mean concentration of three cores is $1.09-1.48 \mu \mathrm{eq} \mathrm{L}^{-1}$ (Cole-Dai and others, 1995), whereas at Byrd station (about $1530 \mathrm{~m}$ a.s.l.) it is $1.52 \mu \mathrm{eq} \mathrm{L}{ }^{-1}$ (Langway and others, 1994). This confirms that at Hercules Névé the influence of sea spray is significant. Generally, the $\mathrm{Cl}^{-}$concentration increases during the coldest season.

Nitrate is produced by the oxidation of $\mathrm{NO}_{\mathrm{x}}$, the main sources of $\mathrm{NO}_{\mathrm{x}}$ in Antarctica being lightning and transport from the stratosphere-troposphere (Herron, 1982; Legrand and Delmas, 1986). At Hercules Névé the median value is $0.45 \mu \mathrm{eq} \mathrm{L}^{-1}$, and the rather low standard deviation (0.19) suggests a low variability of the $\mathrm{NO}_{\mathrm{x}}$ sources. The annual maximum of $\mathrm{NO}_{3}{ }^{-}$concentration generally occurs earlier than $\delta^{18} \mathrm{O}$ in the upper part of the core. A recognisable $\mathrm{NO}_{3}{ }^{-}$seasonal signal occurs along the whole firn core.

Marine biogenic activity, sea salt and sporadic volcanic events are the main sulphate sources. Non-sea-salt (nss) $\mathrm{SO}_{4}{ }^{2-}$ was calculated $\left(\mu \mathrm{eq} \mathrm{L}{ }^{-1}\right)$ by subtracting the sea-water fraction from total $\mathrm{SO}_{4}{ }^{2-}$ according to the equation $\mathrm{nsSSO}_{4}{ }^{2-}$ $=\mathrm{SO}_{4}{ }^{2-}-\left(0.103 \mathrm{Cl}^{-}\right) . \mathrm{As} \mathrm{Na}^{+}$was not measured, $\mathrm{Cl}^{-}$was used as an indicator of sea salt, although a minor percentage of $\mathrm{Cl}^{-}$ can derive from volcanic activity. Negative $\mathrm{nssSO}_{4}{ }^{2-}$ values corresponding to high $\mathrm{Cl}^{-}$concentrations are due both to a chemical reaction between $\mathrm{NaCl}$ and $\mathrm{H}_{2} \mathrm{SO}_{4}$, and to the partition of $\mathrm{Na}_{2} \mathrm{SO}_{4}$ and $\mathrm{HCl}$ produced in that reaction (Legrand and Delmas, 1988). Especially near the coast, negative $\mathrm{nsSSO}_{4}{ }^{2-}$ values could be related to fractionation processes probably occurring on the sea-ice surface (Hall and Wolff, 1998; Wagenbach and others, 1998).

In order to evaluate the volcanic contribution of $\mathrm{SO}_{4}{ }^{2-}$ we considered the background nss sulphate level corresponding to the mean of the positive values of $\mathrm{nssSO}_{4}{ }^{2-}$ $\left(0.93 \mu \mathrm{eq} \mathrm{L}{ }^{-1}\right)$ plus the standard deviation $\left(0.60 \mu \mathrm{eq} \mathrm{L}^{-1}\right)$.

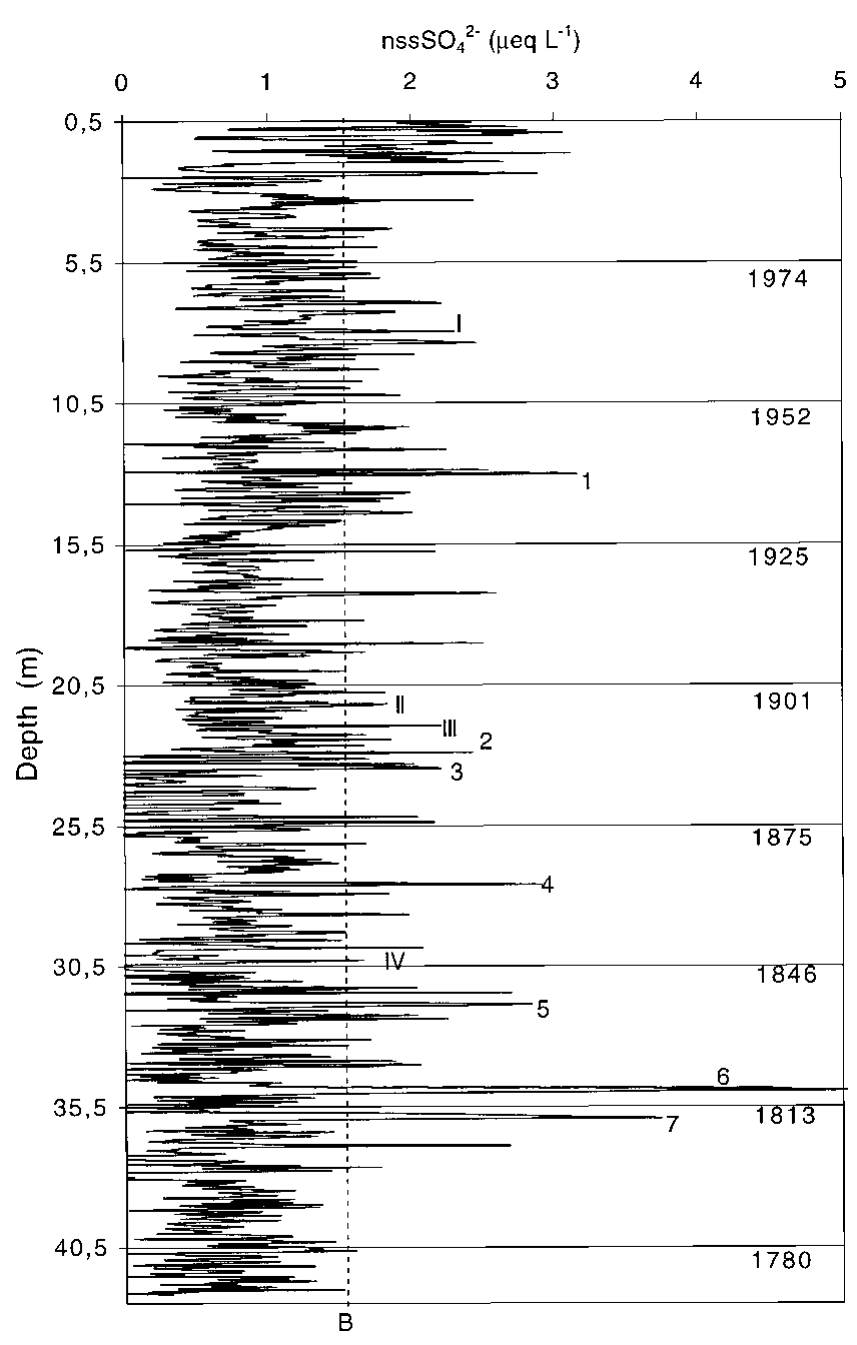

\begin{abstract}
Fig. 4. nss $\mathrm{SO}_{4}{ }^{2-}$ profile at Hercules Névé. Spikes correspond with high probability to the following volcanic eruptions: 1. Rabaul (1937); 2. Tarawera (1886); 3. Krakatoa (1883); 4. Makjan (1861); 5. Coseguina (1835); 6. Tambora (1815); 7. Unknown. Spikes could be referred to: I. Agung; II. Thompson Island (1895); III. Awu (1892); IV. Armagura (1846). B, $n s s \mathrm{SO}_{4}^{2-}$ background ( mean + std dev.).
\end{abstract}

The probability that the peak has a volcanic origin increases with increasing height and area.

The concentration of $\mathrm{nsSSO}_{4}{ }^{2-}$, shows well-defined annual cycles in phase with the $\delta^{18} \mathrm{O}$ profile in the upper part of the core where all chemical species show well-defined annual cycles (Fig. 3) and the highest values correspond to late spring/summer. This relationship between $\mathrm{nssSO}_{4}{ }^{2-}$ and seasonality is confirmed by the significant correlation coefficient between $\delta^{18} \mathrm{O}$ and $\mathrm{nsSSO}_{4}{ }^{2-}(r=0.38, n=1027$, sig. $<0.001 \%$, if samples corresponding to major volcanic eruptions and negative values of $\mathrm{nsSSO}_{4}{ }^{2-}$ are not considered).

As a first step, the core was dated using seasonal variations in $\delta^{18} \mathrm{O}, \mathrm{H}_{2} \mathrm{O}_{2}, \mathrm{NO}_{3}{ }^{-}$and $\mathrm{SO}_{4}{ }^{2-}$ concentrations coupled with the tritium time-marker level; the dating was then fine-tuned, re-examining some doubtful peaks, and using volcanic levels as time markers in order to reduce the error by $2-3 \%$. The overall period of 222 years covers the time interval AD 1770-1992. Figure 4 shows the $\mathrm{nssSO}_{4}{ }^{2-}$ profile and the peaks corresponding to the dates of some known explosive volcanic eruptions. The highest $\mathrm{nssSO}_{4}{ }^{2-}$ concentration is found at 34.80-35.15 m. This layer was dated AD 1816-17 and corresponds to the Tambora eruption (AD 1815). This vol- 
canic signal has been found in the AD 1816 level of many Antarctic and Greenland cores (Legrand and Delmas, 1987; Clausen and Hammer, 1988). Another pronounced volcanic signal was found at 35.71-36 m, 6 years before the previous one (Dai and others, 1991), corresponding to the well-known volcanic event in 1809, called "Unknown" since the eruption centre has not yet been discovered. The eruption marker found at 31.81-32.02 m (dated 1836) was correlated to the Coseguina volcanic eruption (AD 1835). The signal of this eruption has been identified at Byrd station (Langway and others, 1994), at Dome G (Legrand and Delmas, 1987) at the South Pole (Langway and others, 1988; Delmas and others, 1992) and at Mizuho Plateau (Moore and others, 1991). The spike found at $27.6 \mathrm{~m}$ could be related to the Makjan eruption (AD 1861). The signal of this eruption is not clearly separated from Cotopaxi (AD 1856) either at Dome C or at Mizuho Plateau (Legrand and Delmas, 1987; Moore and others, 1991). The Krakatoa (AD 1883) and Tarawera (AD 1886) signals were also identified in many Antarctic cores. The prominent spike at $12.82-13.14 \mathrm{~m}$ is dated 1937. A low signal is present in 1937 at the Siple and Dyer ice cores, and this has been tentatively attributed to the Darney Island eruption (South Sandwich Islands) in 1936 (Cole-Dai and others, 1995). No evident signal was recorded at the South Pole around 1937 (Delmas and others, 1992), whereas at Mizuho Plateau a low peak is present around 1937, but Moore and others (1991) did not record any comment on this peak. Lamb $(1970,1977 b, 1983)$ reports some eruptions in 1937 characterised by a low dust veil index (DVI), whereas Bradley andJones (1992) report an eruption of Rabaul in 1937 characterised by a volcanic explosivity index (VEI) of 4. Since at Hercules Névé the magnitude of the 1937 signal is higher than that of some signals corresponding to eruptions with higher DVI, it is possible that this signal reflects more than one event. Other, less prominent spikes may correspond to known volcanic eruptions, as suggested in the caption to Figure 4, while others could be related to unknown events.

To compare the magnitude of volcanic events at the same site or at different sites, it is useful to use the $\mathrm{SO}_{4}{ }^{2-}$ volcanic fallout. This has been calculated taking into account the difference between the area of the peak and the area due to the background. The fallout of volcanic products depends upon snow-accumulation rate, latitude and season of eruption. Latitude has an important influence on the distribution of volcanic emissions and the partition between the Southern and Northern Hemispheres. It has been found that eruptions occurring at mid- and high latitudes generally do not contribute to volcanic fallout in the opposite hemisphere. Moreover, the efficiency of the atmospheric transport and removal mechanism may vary seasonally. Due to the varia-

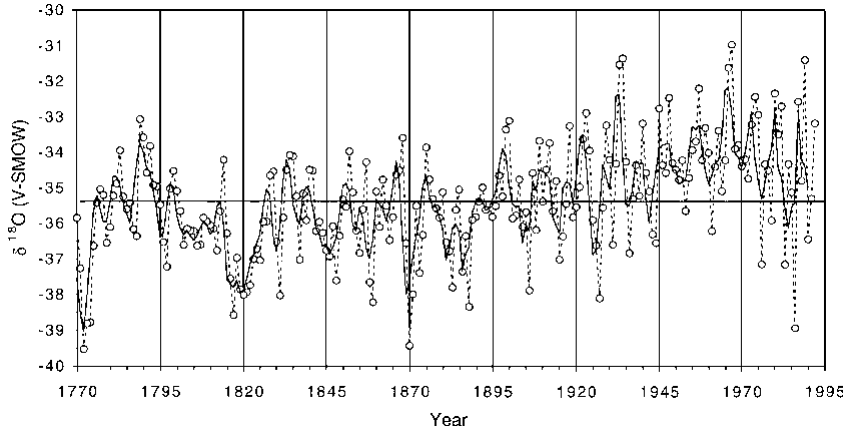

Fig. 5. Mean annual $\delta^{18} \mathrm{O}$ record (dashed line) and 3 year moving average (thick line) of the firn core. The horizontal line represents the overall mean $\delta^{18} \mathrm{O}$ value (-35.38\%o).

bility of these factors the variation of volcanic deposition among different sites is quite high. As a consequence, the deposition differences for any eruption are expected to be high, as reported in Table 1 . In order to obtain a better comparison among different events in a single core or among different cores, a relative deposition may be calculated for the Tambora eruption. These ratios from Hercules Névé are in good agreement with those observed at the South Pole, at Siple station, Antarctic Peninsula, and at Mizuho Plateau, East Antarctica.

The mean annual $\delta^{18} \mathrm{O}$ values, calculated after dating by the multi-parametric approach coupled with stratigraphic time markers, are reported in Figure 5 against time. A smoothed profile (3 year moving average) is also shown in order to reduce the uncertainty due to dating errors and to interannual variability in the $\delta$ profile. Nevertheless, a marked interannual variability was observed in both profiles, the variations being not only related to a temperature effect, due to the large differences in the isotopic composition involved. This pattern has already been observed at other Antarctic sites and may be referred to other factors (apart from the temperature) influencing the isotope composition. These may be the variability of the sea-ice extent (Bromwich and Weaver, 1983), storm frequency, the timing of precipitation events (Steig and others, 1994), seasonal changes in moisture sources and variations in the ratio of summer to winter accumulation rates: in the event of large seasonal changes, this variation may cause similar changes in the mean annual values (Morgan and Van Ommen, 1997). The effect of sea-ice extension reflects the increasing distance between source areas and precipitation sites; a northward increase of sea-ice coverage will cause decreasing values in the isotopic composition of precipitations. On the other hand, an increased storm frequency in winter will cause an ${ }^{18} \mathrm{O}$ enrichment in the mean

Table 1. Volcanic deposition ( $\phi$ in $\mathrm{kg} \mathrm{km}^{-2}$ ) at different sites, and relative deposition $(r$ ) with respect to Tambora eruption

\begin{tabular}{|c|c|c|c|c|c|c|c|c|c|c|}
\hline \multirow[t]{2}{*}{ Site } & \multicolumn{2}{|c|}{ Unknown (1809) } & \multirow{2}{*}{$\begin{array}{c}\text { Tambora (1815) } \\
\phi\end{array}$} & \multicolumn{2}{|c|}{ Coseguina (1835) } & \multicolumn{2}{|c|}{ Krakatoa (1883) } & \multicolumn{2}{|c|}{ Tarawera (1886) } & \multirow[t]{2}{*}{ Source } \\
\hline & $\phi$ & $r$ & & $\phi$ & $r$ & $\phi$ & $r$ & $\phi$ & $r$ & \\
\hline Dome $\mathrm{C}$ & 16.8 & - & $>13$ & 4.6 & - & 5.8 & - & 3.7 & - & Legrand and Delmas (1987) \\
\hline Byrd station & - & - & 24 & - & - & 14 & 0.58 & - & - & Langway and others (1988) \\
\hline South Pole & - & - & 83 & - & - & 11 & 0.13 & - & - & Langway and others (1988) \\
\hline South Pole & $29.8-32$ & $0.41-0.47$ & $67.6-72.3$ & $9.2-12.2$ & $0.13-0.18$ & $8.2-9.4$ & $0.11-0.14$ & $6-13.3$ & $0.08-0.20$ & Delmas and others (1992) \\
\hline Siple station & 53 & 0.46 & 129 & - & - & - & - & - & - & Dai and others (1991) \\
\hline Mizuho & - & 0.18 & 95 & - & - & - & 0.25 & - & 0.24 & Moore and others (1991) \\
\hline
\end{tabular}


annual $\delta$ values. Storms are indeed associated with aboveaverage temperatures advecting warm air to the continent.

Some observations can be made on the mean annual $\delta$ record reported in Figure 5. An overall increasing trend in the mean annual $\delta^{18} \mathrm{O}$ values is apparent in recent times, starting at the end of the 19th century; after AD 1967 a slightly decreasing trend may be observed. An increase of $0.023 \% \mathrm{a} \mathrm{a}^{-1}$ from AD 1890 to 1967 has been calculated. Although care must be taken in comparing different time periods, a value of $0.039 \%$ a ${ }^{-1}$ from AD 1928 to 1993 has been found at this site in a $22 \mathrm{~m}$ firn core (Maggi and others, 1998). Some variance between the two cores may be related to stratigraphic noise due to non-uniform accumulation processes and post-deposition effects. A value of $0.036 \% \mathrm{a}^{-1}$ (AD 1932-91) has been reported by Isaksson and others (1996) at Dronning Maud Land, while for the Antarctic Peninsula a value of $0.046 \% \mathrm{a}^{-1}$ was calculated for a shorter period (AD 1958-80; Peel, 1992). This increasing trend in the $\delta$ values found in the Hercules Névé core confirms what has been observed in other ice-core records from East Antarctica (for a complete review see Mosley-Thompson, 1992). These data suggest a warming trend since 1850, while an opposite tendency has been reported for the Antarctic Peninsula. Since 1975 this trend seems to have been reversed. Recently, Morgan and others (1997) reported for the Dome Summit South (DSS) core at Law Dome, East Antarctica, a relatively rapid temperature increase in the last 100 years.

As regards the bottom section of the firn core, the isotope record suggests "colder" environmental conditions (more negative $\delta^{18} \mathrm{O}$ values) at Hercules Névé for the period AD 1770 1890 , the most negative values being centred around $\mathrm{AD}$ 1870-71, 1816-22 and 1772-74. This colder period seems to correspond to the above-mentioned cold LIA episode, even though particular care must be taken in using this term with a global meaning.

A better understanding of the climatic significance of the isotope variations recorded in the Hercules Névé core requires a comparison with other Antarctic ice-core records. Previous ice-core records from East Antarctica (MosleyThompson, 1992), such as Law Dome (Morgan, 1985), Mizuho (Watanabe and others, 1978) and the South Pole (MosleyThompson and others, 1985), suggest similar colder conditions in the time period encompassing the LIA. The smoothed $\delta \mathrm{D}$ record observed in the $905 \mathrm{~m}$ ice core drilled at Dome $\mathrm{C}(\mathrm{Be}-$ noist and others, 1982) also suggests cooler conditions from AD 1200 to 1800. The Mizuho and Law Dome profiles resemble more closely the Hercules Névé record, with the coldest conditions from AD 1750 to 1850. Morgan and others (1997) found the lowest Holocene $\delta^{18} \mathrm{O}$ values at Law Dome (DSS core) around AD 1800 and referred them to the LIA. The records from the Antarctic Peninsula (e.g. Siple Station: MosleyThompsonand others,1990) seem to show anopposite pattern.

A final consideration concerns the possible link between climate and volcanism. The presence of acid droplets in the stratosphere, reducing atmospheric transmissivity and incoming solar radiation, may cause a temporary decrease of surface temperatures. The relationship between climatic variations and the biggest volcanic eruptions in the past can be investigated by studying the sulphate and the isotope content preserved in ice-core records. For this purpose we considered the Tambora eruption (1815), an event of global importance. There is a long-running debate regarding the climatic effects of this eruption. Angell and Korshover (1985) suggested that the cooling during the decade AD

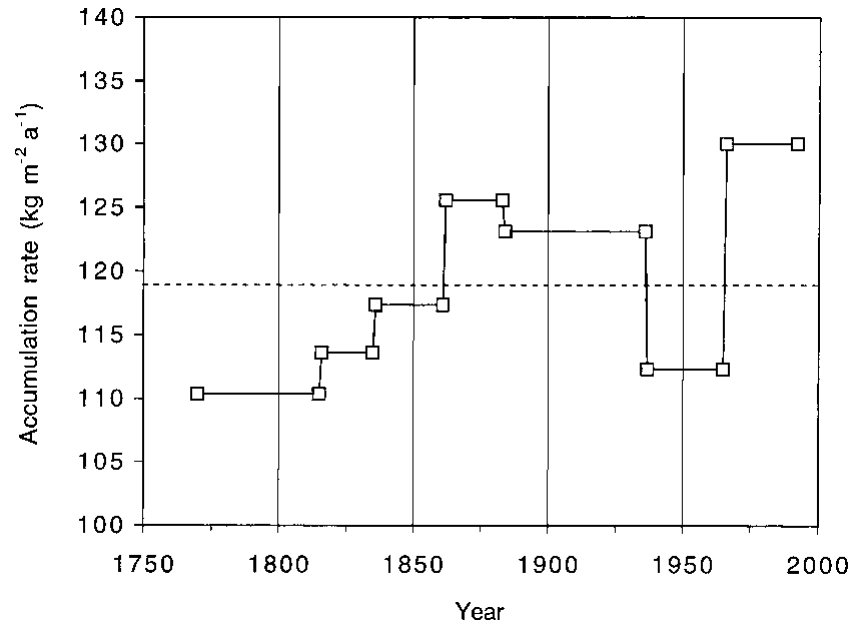

Fig. 6. Mean accumulation rate between different marker levels. The horizontal dashed line represents the overall mean accumulation rate $\left(119 \mathrm{~kg} \mathrm{~m}^{-2} \mathrm{a}^{-1}\right)$.

1810-20 seems to have begun before the Tambora eruption. Dai and others (1991) suggested on the basis of ice-core evidence that the AD 1809 eruption ("Unknown") may have triggered a cooling at the beginning of this period and that the Tambora may have accentuated this tendency. In point of fact, in the Hercules Névé core the most negative $\delta$ values (meaning cooler conditions) are recorded in AD 1816 and 1817 (minimum value). This would seem to suggest a link between surface temperatures and the Tambora eruption, but from the isotope profile reported in Figure 5 it appears that the cooling lasted longer (1815-26). Moreover, no clear relationship between $\delta$ values and volcanic signals can be found in other sections of the core. The Tambora eruption can probably be superimposed on a climatic variation already under way. More direct comparisons between acid spikes and $\delta$ values in ice cores are needed in order to evaluate the possibility that the relation between climate and volcanism could be recorded in this type of archive.

The mean snow-accumulation rate obtained for the whole core is $119 \mathrm{~kg} \mathrm{~m}^{-2} \mathrm{a}^{-1}$ (std dev. = 36.5). If we take into account the mean value calculated between different marker levels $\left(\mathrm{AD} 1966-92=129 \mathrm{~kg} \mathrm{~m}^{-2} \mathrm{a}^{-1} ;\right.$ AD 1937-65 = $112 \mathrm{~kg}$ $\mathrm{m}^{-2} \mathrm{a}^{-1} ;$ AD 1884-1936 = $123 \mathrm{~kg} \mathrm{~m}^{-2} \mathrm{a}^{-1} ;$ AD 1862-83 = 126 $\mathrm{kg} \mathrm{m}^{-2} \mathrm{a}^{-1} ; \mathrm{AD} 1836-61=111 \mathrm{~kg} \mathrm{~m}^{-2} \mathrm{a}^{-1} ;$ AD 1816-35 = $114 \mathrm{~kg}$ $\mathrm{m}^{-2} \mathrm{a}^{-1} ;$ AD $1770-1815=111 \mathrm{~kg} \mathrm{~m}^{-2} \mathrm{a}^{-1}$ ) the snow-accumulation rate did not change significantly throughout the period investigated (Fig. 6). A high interannual variability has been observed since AD 1840, while a lower variability characterises the preceding period. This corresponds to the low isotope values related to the LIA. Higher accumulation rates have been found in a previous drilling at Hercules Névé (Maggi and others, 1998). We must take into consideration that the time intervals covered by these two cores are different and that local variations in snow-accumulation patterns (probably due to wind redistribution) may explain this variance.

\section{GONGLUSIONS}

A record of the volcanic eruptions covering the last 222 years has been reported for northern Victoria Land. Relative volcanic fluxes with respect to Tambora have been determined 
for various eruptions, and quite good agreement has been found with those already reported in the literature.

The importance of time markers constraining ice-core dating has been emphasised in order to obtain a reliable time-scale to reconstruct past environmental changes from ice cores. The reported $\delta^{18} \mathrm{O}$ profile, encompassing part of the LIA, provides additional data for a better understanding of the geographical extension of this "cold" period, confirming the differences between the environmental patterns of the Antarctic Peninsula and East Antarctica already pointed out by previous studies. The recent temperature rises suggested by the Hercules Névé core confirm what has already been observed in other ice-core records recovered from East Antarctica; this increase in $\delta^{18} \mathrm{O}$ values may be related not only to a "warming" phase but also to a change in environmental conditions (e.g. sea-ice extent) in that area and/or an increase in storm frequency leading to more positive isotope values.

Further studies in northern Victoria Land will help to show whether this record is representative of past climatic and environmental changes in the area studied.

\section{AGKNOWLEDGEMENTS}

This research was carried out in the framework of a project on glaciology and paleoclimatology of the Programma Nazionale di Ricerche in Antartide, and financially supported by Ente per le Nuove Tecnologie, l'Energia e l'Ambiente through a cooperation agreement with Università degli Studi di Milano. The authors wish to thank the Italian Antarctic Project and the X Antarctic Expedition logistic staff for their help during the drilling operations.

Special thanks to two anonymous reviewers for helpful suggestions.

\section{REFERENCES}

Angell, J. K. and J. Korshover. 1985. Surface temperature changes following the major volcanic episodes between 1780 and 1980. 7. Climate Appl. Meteorol., 24(9), 937-951.

Baldwin, B., J. B. Pollack, A. Summers, O. B. Toon, C. Sagan and W.V. Camp. 1976. Stratospheric aerosols and climatic change. Nature, $263(5578), 551-555$.

Benoist, J.-P., J. Jouzel, C. Lorius, L. Merlivat and M. Pourchet. 1982. Isotope climatic record over the last $2.5 \mathrm{ka}$ from Dome $\mathrm{C}$, Antarctica, ice cores. Ann. Glaciol., 3, 17-22.

Bradley, R. S. and P. D. Jones. 1992. Records of explosive volcanic eruptions over the last 500 years. In Bradley, R. S. and P. D. Jones, eds. Climate since A.D. 1500. London, etc., Routledge, 606-622.

Briffa, K. R., P. D. Jones, F. H. Schweingruber and T. J. Osborn. 1998. Influence of volcanic eruptions on Northern Hemisphere summer temperature over the past 600 years. Nature, 393(6684), 450-454.

Bromwich, D. H. and C.J. Weaver. 1983. Latitudinal displacement from main moisture source controls $\delta^{18} \mathrm{O}$ of snow in coastal Antarctica. Nature, 301 (5896), 145-147.

Charles, C. D., R. Rind, J. Jouzel, R. D. Koster and R. G. Fairbanks. 1994. Glacial-interglacial changes in moisture sources for Greenland: influences on the ice core record of climate. Science, 263(5146), 508-511.

Clausen, H. B. and C. U. Hammer. 1988. The Laki and Tambora eruptions as revealed in Greenland ice cores from 11 locations. Ann. Glaciol., 10, 16-22.

Cole-Dai, J., L. G. Thompson and E. Mosley-Thompson. 1995. A 485 year record of atmospheric chloride, nitrate and sulfate: results of chemical analysis of ice cores from Dyer Plateau, Antarctic Peninsula. Ann. Glaciol., 21, 182-188.

Dai, J., E. Mosley-Thompson and L. G. Thompson. 1991. Ice core evidence for an explosive tropical volcanic eruption 6 years preceding Tambora. 7. Geophys. Res., 96 (D9), 17,361-17,366.

Dansgaard, W. 1964. Stable isotopes in precipitation. Tellus, 16(4), 436-468.

Delmas, R. J., S. Kirchner, J. M. Palais and J.-R. Petit. 1992. 1000 years of explosive volcanism recorded at the South Pole. Tellus, 44B(4), 335-350.
Gragnani, R., C. Smiraglia, B. Stenni and S. Torcini. 1998. Chemical and isotopic profiles from snow pits and shallow firn cores on Campbell Glacier, northern Victoria Land, Antarctica. Ann. Glaciol., 27, 679-684.

Grove, J. M. 1988. The Little Ice Age. London, Methuen and Co. Ltd.

Groveman, B. S. and H. E. Landsberg. 1979. Simulated Northern Hemisphere temperature departures: 1579-1880. Geophys. Res. Lett., 6(10), 767-769.

Hall, J. S. and E. W. Wolff. 1998. Causes of seasonal and daily variations in aerosol sea-salt concentrations at a coastal Antarctic station. Atmos. Environ., 32(21), 3669-3677.

Hammer, C. U., H. B. Clausen and W. Dansgaard. 1980. Greenland ice sheet evidence of post-glacial volcanism and its climatic impact. Nature, 288(5788), 230-235.

Hansen, J. E., W. C. Wang and A. A. Lacis. 1978. Mount Agung eruption provides test of a global climatic perturbation. Science, 199(4333), 1065-1068.

Hansen, J. E., A. A. Lacis, R. Ruedy and M. Sato. 1992. Potential climate impact of Mount Pinatubo eruption. Geophys. Res. Lett., 19, 215-218.

Herron, M. M. 1982. Impurity sources of $\mathrm{F}^{-}, \mathrm{Cl}^{-}, \mathrm{NO}_{3}{ }^{-}$and $\mathrm{SO}_{4}{ }^{2-}$ in Greenland and Antarctic precipitation. 7. Geophys. Res., 87(C4), 30523060.

Houghton, J.T., L. G. M. Filho, B. A. Callander, N. Harris, A. Kattenberg and K. Maskell, eds. 1996. Climate change 1995: the science of climate change. Cambridge, etc., Cambridge University Press.

Isaksson, E., W. Karlén, N. Gundestrup, P. Mayewski, S. Whitlow and M. Twickler. 1996. A century of accumulation and temperature changes in Dronning Maud Land, Antarctica. 7. Geophys. Res., 101 (D3), 7085-7094.

Johnsen, S. J. 1977. Stable isotope homogenization of polar firn and ice. International Association of Hydrological Sciences Publication 118 (Symposium at Grenoble 1975 - Isotopes and Impurities in Snow and Ice), 210-219.

Jones, P. D. and R. S. Bradley. 1992. Climatic variations over the last 500 years. In Bradley, R. S. and P. D. Jones, eds. Climate since A.D. 1500. London, etc., Routledge, 649-665.

Jouzel, J., L. Merlivat, M. Pourchet and C. Lorius. 1979. A continuous record of artificial tritium fallout at the South Pole (1954-1978). Earth Planet. Sci. Lett., 45(1), 188-200.

Kerr, R. A. 1983. El Chichon climate effect estimate. Science, 219(4581), 157.

LaMarche, V. C., Jr and K. K. Hirschboeck. 1984. Frost rings in trees as records of major volcanic eruptions. Nature, 307 (5947), 121-126.

Lamb, H. H. 1970. Volcanic dust in the atmosphere; with a chronology and assessment of its meteorological significance. Philos. Trans. R. Soc. London, Ser. A, 266(1178), 425-533.

Lamb, H. H. 1977a. Climate: present, past and future. 2: Climatic history and the future. London, Methuen.

Lamb, H. H. 1977b. Supplementary volcanic dust veil assessment. Climate Monitor, 6, 57-67.

Lamb, H. H. 1983. Uptake of the chronology of assessments of the volcanic dust veil index. Climate Monitor, 12, 79-90.

Langway, C. C., Jr, H. B. Clausen and C. U. Hammer. 1988. An inter-hemispheric volcanic time-marker in ice cores from Greenland and Antarctica. Ann. Glaciol., 10, 102-108.

Langway, C. C., Jr, K. Osada, H. B. Clausen, C. U. Hammer, H. Shoji and A. Mitani. 1994. New chemical stratigraphy over the last millennium for Byrd Station, Antarctica. Tellus, 46B(1), 40-51.

Langway, C. C., Jr, K. Osada, H. B. Clausen, C. U. Hammer and H. Shoji. 1995. A 10-century comparison of prominent bipolar volcanic events in ice cores. 7. Geophys. Res., 100 (D8), 16,241-16,247.

Legrand, M. and R. J. Delmas. 1986. Relative contributions of tropospheric and stratospheric sources to nitrate in Antarctic snow. Tellus, 38B (3-4), 236-249.

Legrand, M. R. and R. J. Delmas. 1987. A 220-year continuous record of volcanic $\mathrm{H}_{2} \mathrm{SO}_{4}$ in the Antarctic ice sheet. Nature, 327(6124), 671-676.

Legrand, M. R. and R. J. Delmas. 1988. Formation of HCl in the Antarctic atmosphere. 7. Geophys. Res., 93(D6), 7153-7168.

Maggi, V. and 8 others. 1998.70 years of northern Victoria Land (Antarctica) accumulation rate. Ann. Glaciol., 27, 215-219.

Moore, J. C., H. Narita and N. Maeno. 1991. A continuous 770-year record of volcanic activity from East Antarctica. 7. Geophys. Res., 96 (D9), 17,353-17,359.

Morgan, V. I. 1985. An oxygen isotope-climate record from the Law Dome, Antarctica. Climatic Change, 7 (4), 415-426.

Morgan, V. and T. D. van Ommen. 1997. Seasonality in late-Holocene climate from ice-core records. Holocene, 7(3), 351-354.

Morgan, V. I., C.W. Wookey, Li Jun, T. D. van Ommen, W. Skinner and M. F. Fitzpatrick. 1997. Site information and initial results from deep ice drilling on Law Dome, Antarctica. f. Glaciol., 43(143), 3-10.

Mosley-Thompson, E. 1992. Paleoenvironmental conditions in Antarctica since A.D. 1500: ice core evidence. In Bradley, R. S. and P. D. Jones, eds. Climate since A.D. 1500. London and New York, Routledge, 572-591.

Mosley-Thompson, E., P. D. Kruss, L. G. Thompson, M. Pourchet and P. Grootes. 1985. Snow stratigraphic record at South Pole: potential for paleoclimatic reconstruction. Ann. Glaciol., 7, 26-33. 
Mosley-Thompson, E., L. G. Thompson, P. M. Grootes and N. Gundestrup. 1990. Little Ice Age (neoglacial) paleoenvironmental conditions at Siple Station, Antarctica. Ann. Glaciol., 14, 199-204.

Peel, D. A. 1992. Ice core evidence from the Antarctic Peninsula region. In Bradley, R. S. and P. D. Jones, eds. Climate since A.D. 1500. London and New York, Routledge, 549-571.

Piccardi, G., R. Udisti and F. Casella. 1994. Seasonal trends and chemical composition of snow at Terra Nova Bay (Antarctica). Int. F. Environ. Anal. Chem., 55, 219-234

Robock, A. 1981. The Mount St. Helens volcanic eruption of 18 May 1980: minimal climatic effect. Science, 212 (4501), 1383-1384.

Robock, A. and M. P. Free. 1995. Ice cores as an index of global volcanism from 1850 to the present. F. Geophys. Res., 100 (D6), 11,549-11,567.
Robock, A. and C. Mass. 1982. The Mount St. Helens volcanic eruption of 18 May 1980: large short-term surface temperature observations. Science, $216(4546), 628-630$.

Steig, E. J., P. M. Grootes and M. Stuiver. 1994. Seasonal precipitation timing and ice core records. Science, 266(5192), 1885-1886.

Wagenbach, D. and 7 others. 1998. Sea-salt aerosol in coastal Antarctic regions. 7. Geophys. Res., $\mathbf{1 0 3 ( \mathrm { D } 9 ) , 1 0 , 9 6 1 - 1 0 , 9 7 4 .}$

Watanabe, O., K. Kato, K. Satow and F. Okuhira. 1978. Stratigraphic analyses of firn and ice at Mizuho Station. Mem. Natl. Inst. Polar Res., Special Issue $10,25-47$.

Whitlow, S., P. A. Mayewski and J. E. Dibb. 1992. A comparison of major chemical species seasonal concentration and accumulation at the South Pole and Summit, Greenland. Atmos. Environ., 26A(11), 2045-2054. 